\title{
The World Bank COVID-19 response: Politics as usual?
}

\section{Christopher Kilby ${ }^{1}\left[\right.$ Carolyn McWhirter $^{1}$}

Accepted: 7 July 2021 / Published online: 2 August 2021

(c) The Author(s), under exclusive licence to Springer Science+Business Media, LLC, part of Springer Nature 2021

\begin{abstract}
Do the normal rules of the game apply in international organizations during a global pandemic? We explore this question by comparing regular and COVID-19 World Bank loans. Analyzing lending from April 2, 2020 (the start of COVID19 lending) to December 31, 2020, we find different results for the two types of World Bank loans. Looking at regular loans, countries that vote more in line with the U.S. on UN General Assembly resolutions are more likely to receive loans. For COVID-19 loans, geopolitics is not a significant factor. In contrast to ordinary business, the World Bank appears to have kept politics out of its pandemic response, instead more effectively focusing on provision of an important international public good.
\end{abstract}

Keywords COVID-19 · Pandemic · World Bank · Foreign aid · International public goods

JEL codes F35 $\cdot \mathrm{F} 53 \cdot \mathrm{F} 55 \cdot \mathrm{O} 19$

\section{Introduction}

Consistent with a power-based interpretation of international politics (Morgenthau, 1962), a large body of academic research underscores the role of geopolitics in the allocation of foreign aid, both bilateral (Alesina \& Dollar, 2000) and multilateral (Kaya, 2015; Vreeland \& Dreher, 2014). Even food aid and disaster relief are not wholly immune; there is evidence that donor decisions reflect a political calculus in some cases (Annen \& Strickland, 2017; Drury et al., 2005; Ruttan, 1996) but not in others (Kevlihan et al., 2014). As donor countries and international institutions

\section{Responsible editor Axel Dreher}

Christopher Kilby

chkilby@yahoo.com

1 Villanova University, Villanova, PA, USA 
respond to the COVID-19 pandemic impacting emerging and developing economies, what role will geopolitics play? Is it politics as usual-or will the international public goods (IPG) nature and immediacy of the crisis lead to a different result?

We explore this question for the case of the World Bank, the leading multilateral development agency both in terms of its lending volume to low- and middle-income countries and its role as agenda setter. The World Bank has taken a prominent role in the global pandemic response, and its website provides lending information in real time (a feature we exploit for this analysis). Despite a charter that prohibits political considerations, there is ample evidence of politics in World Bank operations, including the speed of project preparation (Kilby, 2013b), lending decisions (Dreher et al., 2009), disbursement (Kersting \& Kilby, 2016; Kilby, 2013a), enforcement of conditionality (Clark \& Dolan, 2021), project evaluation (Kilby \& Michaelowa, 2019), and debt sustainability rating (Lang \& Presbitero, 2018). While anecdotes suggest influence by various stakeholders, there is substantial statistical evidence of U.S. influence, evidence underscored by patterns tied to U.S. domestic politics (Kersting \& Kilby, 2021).

The cost of geopolitical influence in terms of reduced effectiveness can be high. Development funds allocated to further geopolitical goals are less likely to go to those in need or to reach governments that will use them effectively to reduce poverty (Collier \& Dollar, 2002; Zimmerman, 1993). In addition, allocation based on geopolitics undermines recipient government incentives to use funds for their putative purpose or to comply with policy reforms linked to aid. As a result, even funds reaching the "right" government may be less effective. Aid allocated based on geopolitical considerations shows worse outcomes at the project level (Dreher et al., 2013; Kilby, 2015) and is less effective at promoting growth at the country level (Dreher et al., 2018; Kilby \& Dreher, 2010).

Scholars have explored the geopolitics of disaster relief for a number of reasons. The U.S. "Food Power" doctrine, especially associated with Henry Kissinger in the 1970s (Ruttan, 1996), highlights that essential resources are well-suited as foreign policy tools. Drury et al. (2005) argue that disaster relief provides a "strong test" for the politicization of aid because of the official position and public perception that disaster relief is only about need. Finding politicization in disaster relief, when lives are directly and immediately at stake [with 8500 natural disaster-related deaths, along with nearly 100 million people affected in 2020 alone (EM-DAT, 2020)], calls into question donor motives for all forms of aid. To the extent that geopolitics distort the international response to these tragedies, the negative welfare effects could be enormous.

In contrast to the typical disaster relief case, the COVID-19 pandemic-specifically, the fight to contain the spread of the virus-has the characteristics of an international public good. Reducing the prevalence of novel coronavirus infection among people from Country A provides a degree of protection to people from Country B who interact with them, and in turn to people from Country $\mathrm{C}$ who interact with people from Country B and so on. This "non-infection benefit" is a public good because it is nonrival in consumption and nonexcludable; it is an international public good because the actions of one country benefit other countries (Kanbur, 2002). The World Bank (2020b, p. 7) recognizes this in its internal analysis: "A key justification 
for the [World] Bank's involvement, therefore, is the Global Public Goods aspect of the COVID-19 response." Most other natural disasters (famines, floods, tsunamis, etc.) do not have these IPG characteristics so that the benefits of disaster relief aid are limited to people in the recipient country. ${ }^{1}$ In the case of COVID-19, as with other diseases like Ebola, previous pandemics like the H1N1 flu, and the continuing threat of climate change, developed countries-including the U.S. and other major World Bank shareholders-stand to benefit from World Bank programs to support production of international public goods. However for COVID-19, the magnitude of the crisis and particularly the immediacy of the problem in rich countries - the rate of infection, the rapidly rising number of deaths, and the crippling economic consequences of full or partial shutdowns - suggest a very large IPG benefit and thus raise the possibility that decision-making at the World Bank may be different because donors themselves benefit. As Bermeo (2018, p. 4) argues, aid donors often "pursue a strategy of self-interested development promotion abroad." With the COVID-19 pandemic, this logic suggests donors may refrain from interfering in the allocation of World Bank COVID loans.

Analyzing lending from April 2, 2020 (the start of COVID-19 lending) to December 31, 2020, we find evidence of a link between geopolitics and access to regular World Bank funds but no evidence of such a link for World Bank COVID funds. Using a two-part model, our estimation finds that countries voting more in line with the U.S. in the UN General Assembly (UNGA) are more likely to receive regular World Bank funding. In contrast, voting alignment does not play a significant role in access to COVID funding or, for countries that do receive funds, in how much funding (regular or COVID) countries receive. The link to geopolitics in selection for regular World Bank lending holds over longer timeframes and results for both COVID and regular lending hold when we include a wide range of variables that reflect borrowing country governance and policy or if we limit the sample to supplydetermined concessional lending.

Section 2 outlines the World Bank COVID-19 response to date. Section 3 turns to the main empirical analysis. Section 4 explores several robustness checks, including concerning identification. Section 5 concludes, summarizing our findings relating geopolitics to regular lending but not to COVID lending, and explores the wider implications.

\section{World Bank COVID-19 response}

The World Bank responded rapidly to the pandemic, announcing in March 2020 that it could provide up to $\$ 160$ billion over the next 15 months, a significant increase above its normal lending level and by far the largest amount of any multilateral

\footnotetext{
1 There are, of course, also potential commercial benefits to firms and contractors supplying relief aid but these are private goods (being both rivalrous and excludable).
} 
development bank (World Bank, 2020a). ${ }^{2}$ Between April 2 and December 31, 2020, the direct pandemic response included 138 new country-specific COVID-19 IBRD/ IDA loans to 93 countries. ${ }^{3}$ These loans totaled $\$ 18$ billion and ranged from $\$ 2.5$ million loans to Kiribati, the Marshall Islands, and Sao Tome and Principe to \$1 billion loans to Brazil, India, and Mexico. In addition, more than $\$ 2.5$ billion in funding previously approved for over 100 other projects has been redirected toward COVID-19 response (World Bank, 2020a, 2020b). ${ }^{4}$ At the same time, the World Bank continued its regular lending, mostly for projects prepared before the start of the pandemic. From April to December, the World Bank approved 232 non-COVID loans to 87 countries, totaling $\$ 34.6$ billion.

\footnotetext{
2 This figure includes IFC and MIGA funds; the figure for IBRD and IDA commitments is \$104 billion. Actual IBRD/IDA commitments through June 2021 were $\$ 98$ billion (World Bank, 2021b). Morris et al. (2021) expect $60 \%$ of these commitments to disburse by that point, a lower percentage than they believe appropriate given the scale of the pandemic but a substantially higher percentage than is typical in past years. The World Bank (2020b, 36), for its part, states that it aims to disburse "the largest share...within 12 to 18 months," details a number of streamlined administrative procedures, and notes that IDA lending contains a greater-than-usual share of fast disbursing development policy finance, but also notes that disbursement may be delayed by supply chain problems.

3 Throughout this paper, we focus exclusively on International Bank for Reconstruction (IBRD) loans and International Development Association (IDA) credits and grants. Our COVID loan designations are based primarily on project titles (including the terms "COVID" and "pandemic"). Among these, we checked cases where preparation may have started before the pandemic (as indicated by low project identification numbers; see Fig. 3 and Kilby (2013b)) to verify that their central focus was COVID-related. We also reviewed other projects with the word "emergency" in their titles to determine if the emergency was the pandemic. All results reported are based on IBRD and IDA lending only, excluding trust funds and other product lines (the sums for these are small) plus any multi-country loans where commitments cannot be attributed to individual countries.
}

The World Bank has provided various COVID lending figures in press releases and fact sheets. An October 14, 2020 factsheet (World Bank, 2020e) indicates \$22 billion in IBRD/IDA commitments for COVID-related activities, $36 \%$ for "strengthening policies, institutions and investment for rebuilding better" (the 4th of four thematic pillars the World Bank articulated). Interpreting this category as "business as usual" rather than COVID-related, the figure is $\$ 14$ billion through early October, in line with our calculations.

Throughout this paper, as is common in the empirical literature on lending by international financial institutions (IFIs), we use the terms project and loan synonymously. In fact, individual projects are often financed with more than one simultaneously issued loan or credit, reflecting different sources of funding, different currencies, and, in some cases, different financing terms. Following World Bank practice, all such loans are bundled together and treated as a single project/loan. Again following the literature and World Bank practice, the only time we treat different loans for the same project separately is when there are supplemental loans (also called additional finance $(\mathrm{AF})$ ) that are approved separately at a later point in time and added to an existing project.

${ }^{4}$ In some cases, this follows a formal provision in existing project agreements called a "Contingent Emergency Response Component" (CERC) that allows the borrowing government to convert part of the loan or credit commitment to emergency funds. For example, the World Bank approved a \$200 million IDA credit to Ghana in May 2019, for the Greater Accra Resilient and Integrated Development Project (Project ID P164330), the primary goal of which was improved flood and waste management. This loan included a \$65 million CERC. On March 25, the World Bank approved activation of the CERC. On April 2, the World Bank also approved a \$35 million COVID-19 Emergency Preparedness and Response Project and on November 10, it approved a $\$ 130$ million AF loan for this project.

Our analysis focuses on new lending during the pandemic (e.g., Ghana's Emergency Preparedness and Response Project and its AF). We do not analyze redirection of previously committed funds to COVID relief (e.g., Ghana's CERC) since that depends also on a country's pre-pandemic situation, i.e., having undisbursed balances, CERCs, etc. 
Figure 1 presents lending month by month, separating 2020 lending into regular and COVID loans and also including 2019 lending for comparison. Loan approvals are seasonal, with spikes at the end of each fiscal quarter and at the end of the fiscal year (May/June). Regular lending was higher in 2020 than in 2019 due to an increase in concessional IDA loans to the poorest countries (rising from $\$ 16.9$ billion to $\$ 27.7$ billion). Figure 2 presents the same information but tracking the number of loans; it shows the initial COVID response in April provided many small loans.

Figure 3 illustrates how long projects have been in the pipeline prior to approval by plotting project identification numbers (Project IDs). World Bank staff bill worktime to activities tracked by Project IDs. Sequentially generated Project IDs are usually assigned when preparation work begins and so serve as proximate measures of identification dates (Kilby, 2013b), i.e., for a given approval date, higher Project ID numbers indicate shorter preparation periods. The top panel of Fig. 3 shows Project IDs for regular loans approved April 2 to December 31, 2020 (AF as dashed lines); the bottom panel is for COVID loans approved during the same period. Except for a few cases (repurposed older Project IDs), COVID loans show the expected rapid response time (i.e., short preparation periods). ${ }^{5}$

Figure 4 reports the distribution of the number of regular and COVID loans across countries. Countries received up to six regular loans, with most receiving 0 to 4. They received up to two COVID loans, many with none, most with 1 , and many with $2 .^{6}$

The data we analyze are IBRD and IDA commitments, not disbursements. Duggan et al. (2020) compare World Bank performance through early October 2020 against both its stated targets and its performance during the Global Financial Crisis. The World Bank appears to be on target for commitments but lagging substantially with regard to disbursements and net flows.

What does the World Bank say about its own lending? Most of the World Bank's public statements elide non-COVID and COVID lending, e.g., touting a plan for new lending of $\$ 160$ billion from March 2020 to June 2021 that, on closer examination, is a combination of regular lending and COVID emergency loans. Public documents (e.g., World Bank, 2020c) repeat emphasis on selectivity and "Rebuilding Better" or "Build Back Better," consistent with criticism that World Bank president Malpass sees the pandemic as providing the World Bank with extra leverage over policy in borrowing countries (Bretton Woods Project, 2020; Dimakou et al., 2021). These public documents refer to three stages ("Relief"; "Restructuring"; "Resilient Recovery") and four pillars ("Saving Lives"; "Protecting the Poor \& Vulnerable"; "Ensuring Sustainable Business Growth \& Job Creation"; "Strengthening Policies,

\footnotetext{
5 The right-hand side regular loan cluster is disproportionately AF loans (dashed lines) that add funds to existing projects and are known for short preparation periods (Kilby 2013b). For more on AF loans, see Kersting and Kilby (2019). The World Bank (2020c, 18) states that emergency health projects approved to respond to the pandemic had an average preparation time of 27 days as of June 2020.

6 We define countries as eligible to borrow based on WDI (2020) coding.
} 
Institutions, and Investments for Rebuilding Better") as providing structure to the lending process.

Drawing instead on material presented to the World Bank's Executive Directors, a key document says that loans "will provide emergency financing, policy advice, and technical assistance, building on existing instruments to support IDA and IBRD eligible countries in addressing the health related and broader development impacts of COVID-19.... allowing a rapid response to short-term needs. Also, depending on needs, the Program may provide for a second project in a given country depending on the availability of resources" (World Bank, 2020b, pp. 13-14). This document also states: "as part of the proposed IDA19 commitments [i.e., the conditions agreed on to approve the 19th replenishment of IDA funds], the World Bank is committed to 'support at least 25 IDA countries to implement pandemic preparedness plans through interventions (including strengthening institutional capacity, technical assistance, lending and investment)"' (World Bank, 2020b, p. 14). We have not found major revisions to online Operations Manuals that would provide a more detailed explanation how the World Bank makes COVID-19-related allocation decisions; this is confirmed by the World Bank's Operations Help Desk. ${ }^{7}$ We turn now to our own analysis.

\section{Main empirical analysis}

Following much of the literature on aid allocation, we use a two-part model, separately estimating a selection equation and a conditional allocation equation (Cameron \& Trivedi, 2005, pp. 544-546). The unit of analysis is the country. The selection equation examines whether a country received a particular type of IBRD loan/ IDA credit commitment during the time period. The selection equation estimation uses the full sample of countries eligible to borrow from the World Bank and is estimated via probit. The conditional allocation equation examines how much funding selected countries receive (measured as the log of IBRD and IDA commitments approved by the World Bank for the country during the time period). The conditional allocation sample is restricted to countries that received one or more such commitments and is estimated via OLS. In both cases, we consider only countryspecific loans (not regional loans).

To capture the influence of geopolitics, we include the two most common measures from the literature on the political economy of IFIs. The first is UNGA Voting, voting alignment with the U.S. on UNGA resolutions designated as important by the U.S. State Department (Wang, 1999). This variable includes only roll call votes on UNGA resolutions that are designated as important by the U.S. State Department and that pass. ${ }^{8}$ The second is UNSC membership, a dummy indicating nonpermanent

\footnotetext{
7 Personal correspondence, June 30, 2021.

${ }^{8}$ For each such vote, we record a 1 if the country votes the same as the U.S., 0 if it votes opposite the U.S., and $1 / 2$ if it abstains or is absent when the U.S. votes. Our voting measure is the average of these scores across all votes on UNGA resolutions designated as important by the U.S. State Department in the calendar year. Since the vast majority of UNGA votes take place in November and December each year, we use the alignment measure from the previous year (2019).
} 
Distribution of regular \& COVID loan amounts by month

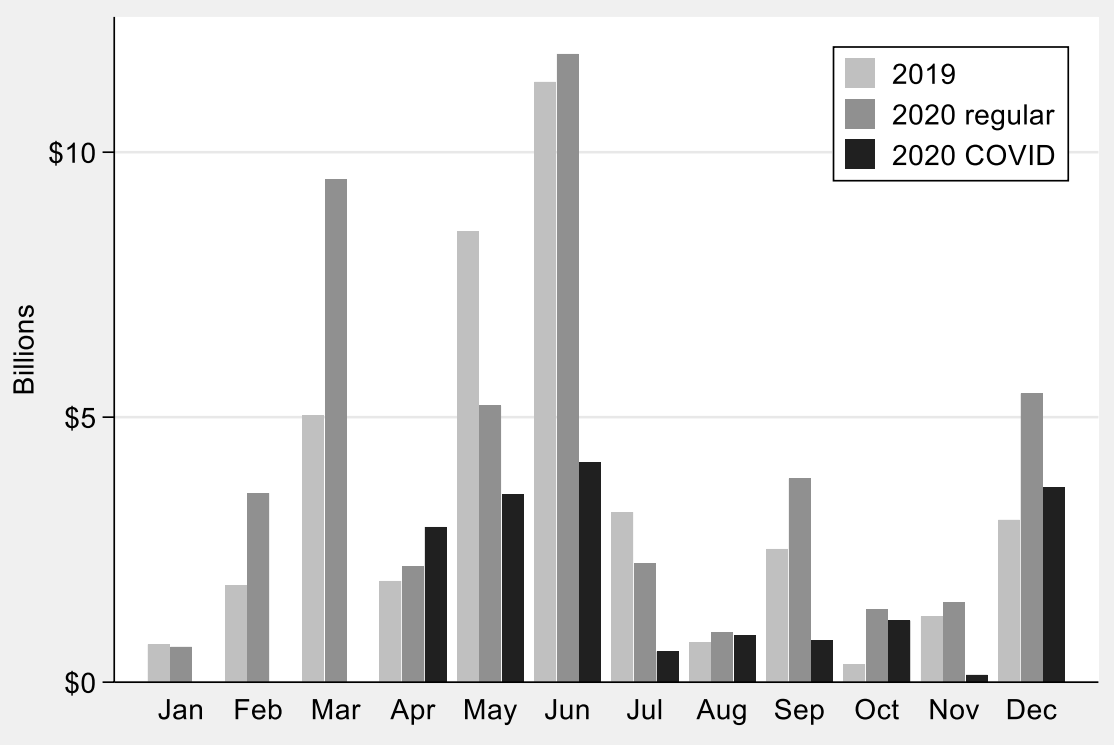

Fig. 1 Amount by month

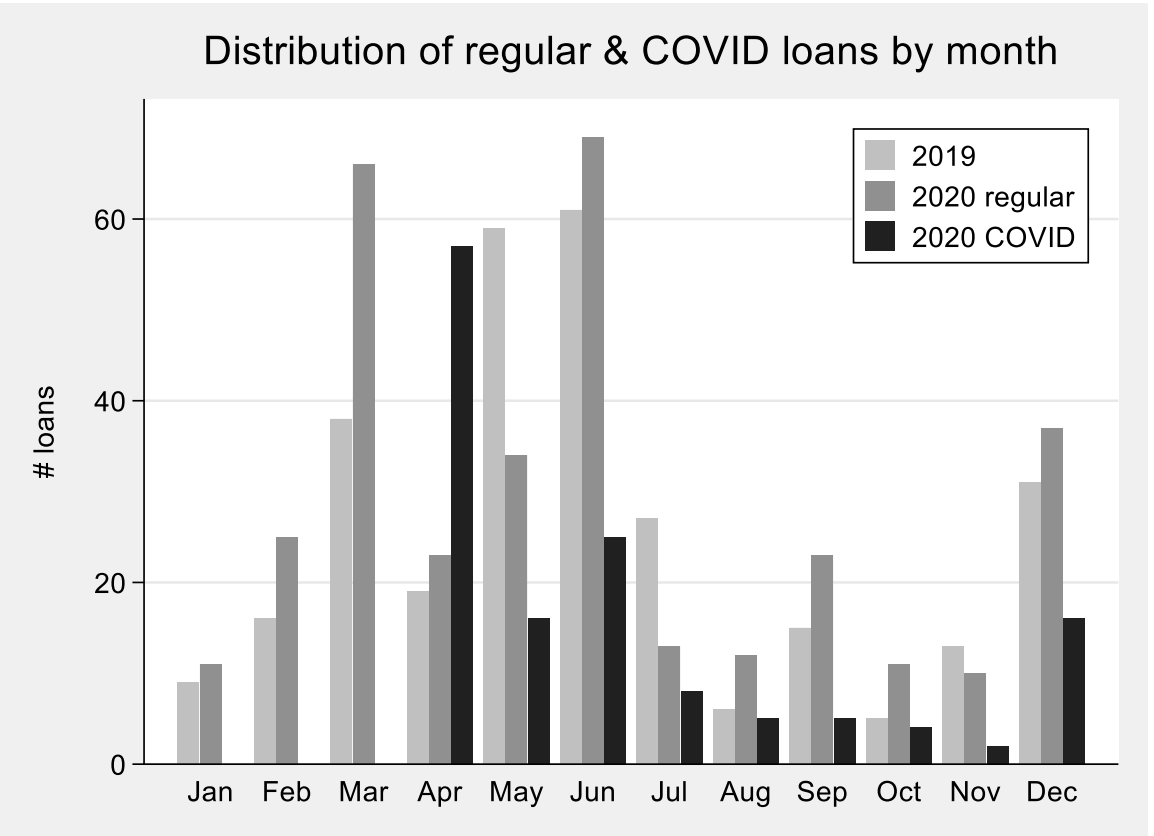

Fig. 2 Number of loans by month 


\section{Project IDs for regular \& COVID loans Approved April 2-December 31, 2020}
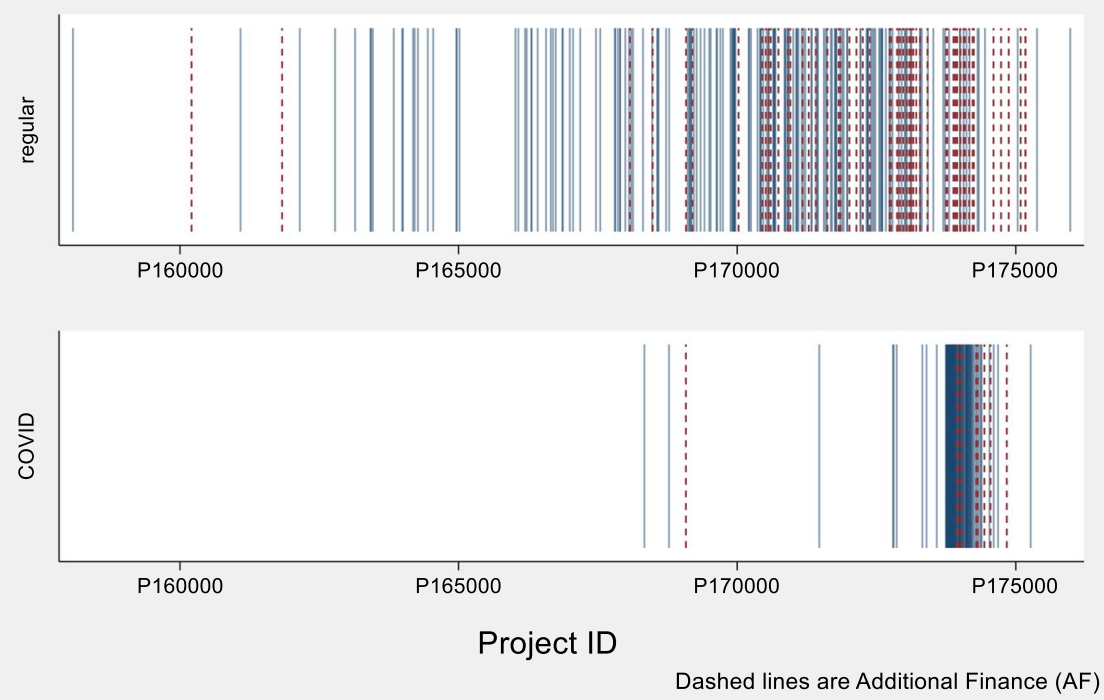

Fig. 3 Project IDs

\section{Distribution of regular \& COVID loans across countries}

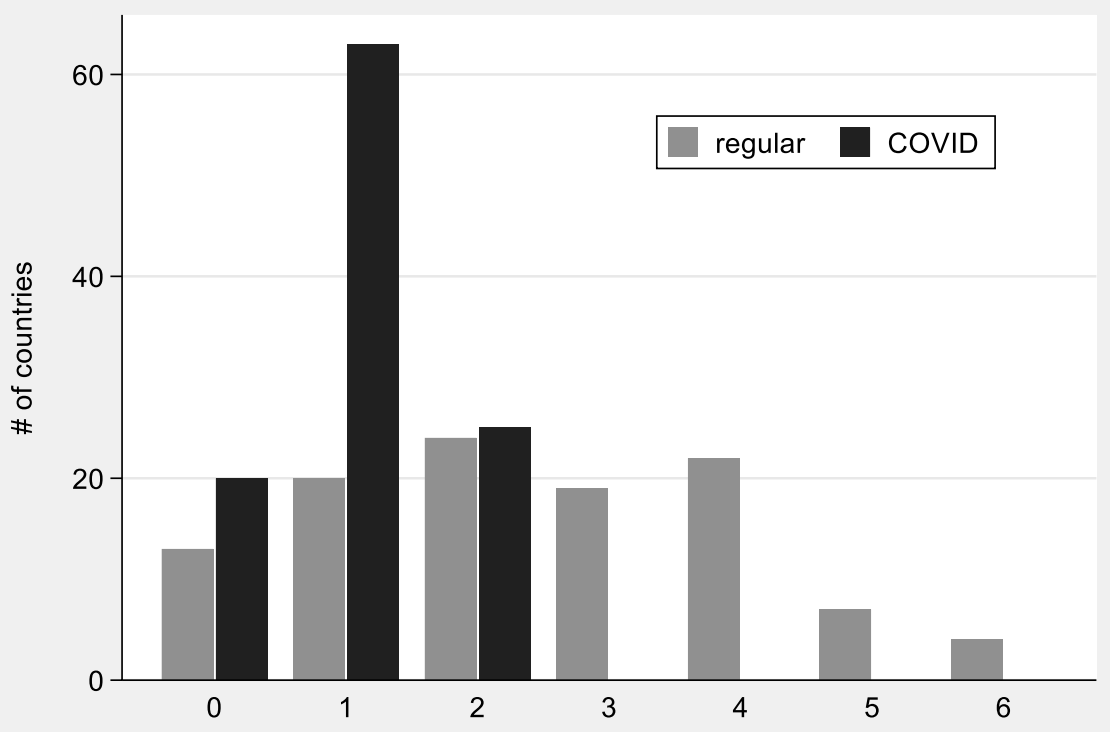

Fig. 4 Loans per country 
UN Security Council (UNSC) membership (Dreher et al., 2009; Vreeland \& Dreher, 2014). ${ }^{9}$

Due to the nature of our question (a one-time event), our main analysis is crosssectional rather than panel. For this reason, we are particularly concerned that countries politically aligned with the U.S. might also pursue economic policies the U.S. (hence the World Bank) would favor. To avoid the omitted variable bias this would introduce, we include not only the usual GDP per capita and population (both logged) to capture need and creditworthiness but also direct measures of economic policy: control of corruption and regulatory quality. We control for the severity of the COVID-19 crisis by including the number of confirmed cases, the number of deaths, and the expected impact of the pandemic on growth (based on revisions to IMF World Economic Outlook forecasts). ${ }^{10}$ Given the shortcomings of (and differences between) countries' reporting of COVID-19 statistics, one might prefer to use an excess mortality measure instead. Unfortunately, these data are not yet widely available and, perhaps more importantly, were not available to World Bank management when making lending decisions whereas the COVID-19 statistics were. Finally, we include dummy variables indicating eligibility to borrow from just the concessional window of the World Bank (IDA) or from both windows (blend). See Tables 1 and 2 for variable definitions, data sources, and descriptive statistics. ${ }^{11}$

Table 3 reports the main estimation results. The sample for the selection equation covers 141 countries, all those eligible to borrow from the World Bank except Syria, which lacks an IMF growth forecast, and Yemen and Kosovo as neither country voted in the UNGA in 2019. Of these, 108 countries (76\%) received country-specific IBRD or IDA commitments in 2020. Eighty-seven $(61 \%)$ received regular funding; of these 15 received only this type (no COVID funding). Ninety-three (65\%)

\footnotetext{
9 We use membership in year $t$ (rather than lagged) because it is generally well known in advance which countries will hold these seats. Results for the UNSC variable are weaker if we lag it (with little effect on results for other variables).

${ }^{10}$ COVID-19 numbers are cumulative as of June 30, 2020. Results are similar using figures from April 1 (just prior to the start of COVID lending) and somewhat less significant (for the COVID coefficients) using end-of-year data; other results do not depend on which measure we choose. Looking at the expected impact of growth follows from the World Bank's internal justification for lending: "Potential tightening of credit conditions, weaker growth, and the diversion of expenditures to fight the pandemic are likely to cut into government revenues and their ability to invest to meet infrastructure, health, education, and other priority development goals" (World Bank, 2020b, 11).

11 It is possible that we still face an omitted variable problem, e.g., if other factors related to economic policy that matter to the World Bank are correlated with our geopolitical variables. Vreeland and Dreher (2014) explore this in depth in the case of nonpermanent UNSC membership and conclude that nonpermanent membership appears to be exogenous in this context. To address the endogeneity issue for UNGA voting alignment, one might consider an instrumental variables approach. However, finding a valid instrument that would generate meaningful results is problematic. If we interpret UNGA alignment as vote buying, identifying exogeneous variation in voting (e.g., due to quirks in the process) is appealing. However, if we interpret UNGA alignment as reflecting country (or government) preferences, then the exogenous component of voting could be systematically unrepresentative of preferences and therefore fail to capture the quantity of interest. This argues for including sensible controls and against trying to uncover a "clever" natural experiment. The robustness section below explores a range of other controls. For a more general discussion about the local average treatment effect (LATE) versus the average treatment effect (ATE), see Deaton (2010) and Gibson (2019).
} 


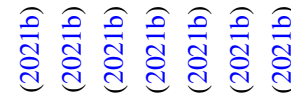

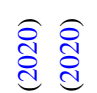

s

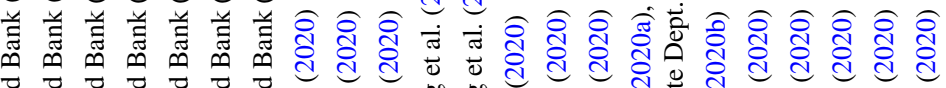

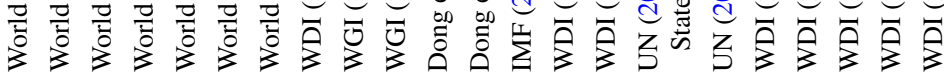

๙ิ

ปั

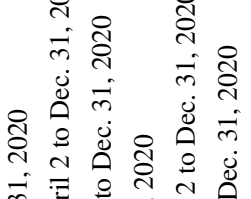

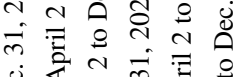

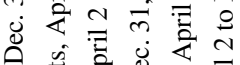

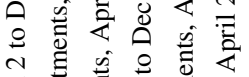

글

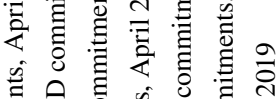

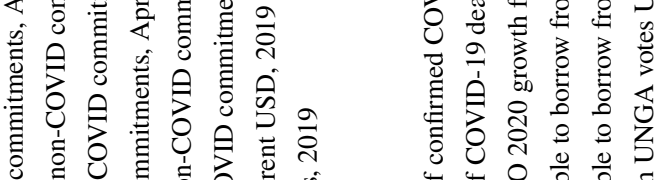

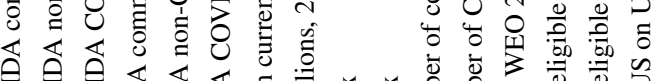

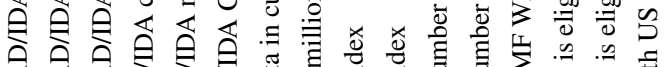

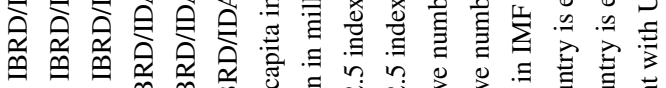

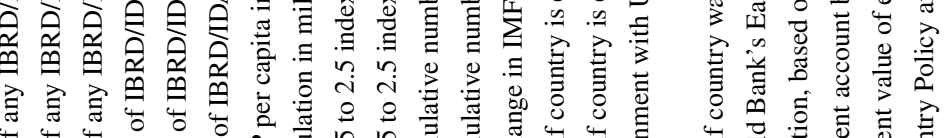

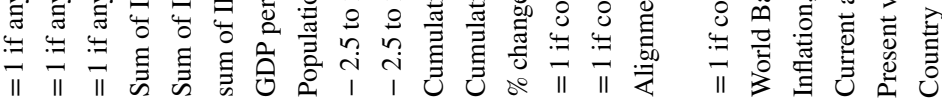

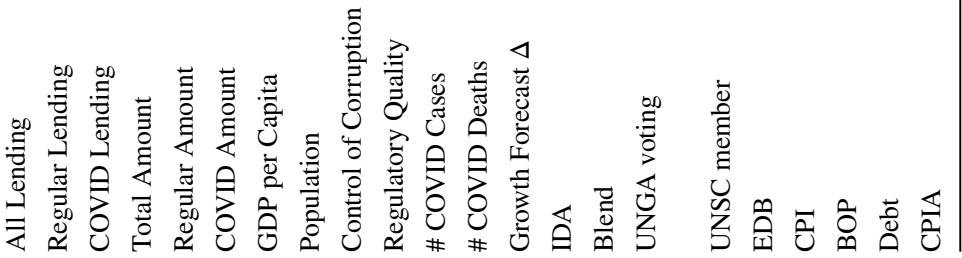


Table 2 Descriptive statistics

\begin{tabular}{|c|c|c|c|c|}
\hline & Mean & sd & Min & $\operatorname{Max}$ \\
\hline \multicolumn{5}{|l|}{ Selection equation } \\
\hline All lending & 0.766 & 0.425 & 0 & 1 \\
\hline Regular lending & 0.617 & 0.488 & 0 & 1 \\
\hline COVID lending & 0.660 & 0.476 & 0 & 1 \\
\hline GDP per capita & 5149.7 & 4618.0 & 126.9 & $19,896.5$ \\
\hline Population & 45.66 & 167.2 & 0.0116 & 1397.7 \\
\hline Control of corruption & -0.456 & 0.679 & -1.774 & 1.618 \\
\hline Regulatory quality & -0.451 & 0.681 & -2.359 & 1.224 \\
\hline \# COVID cases & $39,724.1$ & $145,145.7$ & 0 & $1,402,041$ \\
\hline \# COVID deaths & 1578.7 & 6596.6 & 0 & 59,594 \\
\hline Growth forecast $\Delta$ & -6.854 & 5.625 & -58.63 & -0.500 \\
\hline IDA & 0.397 & 0.491 & 0 & 1 \\
\hline Blend & 0.106 & 0.309 & 0 & 1 \\
\hline UNGA voting & 0.360 & 0.129 & 0.100 & 0.800 \\
\hline UNSC member & 0.0496 & 0.218 & 0 & 1 \\
\hline $\mathrm{N}$ & 141 & & & \\
\hline \multicolumn{5}{|c|}{ Conditional allocation: all lending } \\
\hline Total amount & 481.7 & 755.6 & 2.500 & 4854.0 \\
\hline GDP per capita & 4146.2 & 4015.6 & 126.9 & $17,401.7$ \\
\hline Population & 53.59 & 189.8 & 0.0116 & 1397.7 \\
\hline Control of corruption & -0.467 & 0.663 & -1.774 & 1.618 \\
\hline Regulatory quality & -0.482 & 0.555 & -2.203 & 1.122 \\
\hline \# COVID cases & $40,043.1$ & $152,047.5$ & 0 & $1,402,041$ \\
\hline \# COVID deaths & 1830.4 & 7454.5 & 0 & 59,594 \\
\hline Growth forecast $\Delta$ & -6.161 & 3.483 & -32.85 & -1.161 \\
\hline IDA & 0.491 & 0.502 & 0 & 1 \\
\hline Blend & 0.130 & 0.337 & 0 & 1 \\
\hline UNGA voting & 0.364 & 0.124 & 0.117 & 0.800 \\
\hline UNSC member & 0.0556 & 0.230 & 0 & 1 \\
\hline $\mathrm{N}$ & 108 & & & \\
\hline \multicolumn{5}{|c|}{ Conditional allocation: regular lending } \\
\hline Regular amount & 395.9 & 508.8 & 2.500 & 2490 \\
\hline GDP per capita & 3518.6 & 3275.1 & 126.9 & $14,853.2$ \\
\hline Population & 63.61 & 210.3 & 0.0116 & 1397.7 \\
\hline Control of corruption & -0.474 & 0.661 & -1.774 & 1.618 \\
\hline Regulatory quality & -0.502 & 0.574 & -2.203 & 1.122 \\
\hline \# COVID cases & $44,737.4$ & $167,509.7$ & 0 & $1,402,041$ \\
\hline \# COVID deaths & 2092.6 & 8216.3 & 0 & 59,594 \\
\hline Growth forecast $\Delta$ & -6.111 & 3.733 & -32.85 & -1.161 \\
\hline IDA & 0.540 & 0.501 & 0 & 1 \\
\hline Blend & 0.149 & 0.359 & 0 & 1 \\
\hline UNGA voting & 0.375 & 0.128 & 0.150 & 0.800 \\
\hline
\end{tabular}


Table 2 (continued)

\begin{tabular}{llclc}
\hline & Mean & sd & Min & Max \\
\hline UNSC member & 0.0460 & 0.211 & 0 & 1 \\
N & 87 & & & \\
Conditional allocation: COVID lending & & & & \\
COVID amount & 189.0 & 401.4 & 2.500 & 2900.0 \\
GDP per capita & 4035.7 & 3997.3 & 261.2 & $17,401.7$ \\
Population & 59.80 & 203.8 & 0.0588 & 1397.7 \\
Control of corruption & -0.496 & 0.612 & -1.539 & 1.618 \\
Regulatory quality & -0.465 & 0.481 & -1.510 & 1.122 \\
\# COVID cases & $42,981.4$ & $161,281.5$ & 0 & $1,402,041$ \\
\# COVID deaths & 1708.1 & 7070.9 & 0 & 59,594 \\
Growth forecast $\Delta$ & -6.155 & 3.620 & -32.85 & -1.450 \\
IDA & 0.495 & 0.503 & 0 & 1 \\
Blend & 0.108 & 0.311 & 0 & 1 \\
UNGA voting & 0.360 & 0.121 & 0.117 & 0.750 \\
UNSC member & 0.0430 & 0.204 & 0 & 1 \\
N & 93 & & & \\
\hline
\end{tabular}

received COVID funding; of these 21 received only this type (no regular funding). For Columns (1) to (3), Table 3 reports average marginal effects (probability derivatives for continuous variables and probability differentials for dummy variables).

The first three columns report selection results. The dependent variable in Column (1) is All Lending, equal to 1 if the country received any IBRD/IDA commitments (regular or COVID). Only three covariates are statistically significant. Ceteris paribus, IDA and blend countries are more likely to receive commitments. The likelihood of receiving commitments is marginally related to the severity of the pandemic as measured by \# COVID Cases. Neither geopolitical variable is statistically significant, though both enter with a positive sign. Column (2) reports results for Regular Lending, equal to 1 if the country received non-COVID commitments. The average marginal effect for UNGA Voting is more than twice as large and is now highly statistically significant. Column (3) shifts the dependent variable to COVID Lending, equal to 1 if the country received COVID-specific commitments. In contrast to Regular Lending, for COVID Lending voting alignment in the UNGA is not a significant factor. The other notable differences are that governance (measured by Control of Corruption) is marginally significant for Regular Lending but not for COVID Lending and that there is a somewhat stronger positive response of COVID Lending to \# COVID Cases as compared to overall lending or Regular Lending.

Columns (4) to (6) report results for conditional allocation. Column (4) examines all commitments for the 108 countries that did receive World Bank commitments in 2020. While Population was not relevant in selection, it plays an important role in conditional allocation; for every $1 \%$ increase in population, World Bank loan amount increases by about $0.6 \%$. Countries with access 
to both IBRD and IDA funding also receive more, as do countries with higher reported COVID case numbers. Control of Corruption, and UNGA Voting enter with positive coefficient estimates but are only marginally significant. Column (5) looks only at regular lending; in this specification, \# COVID Cases and the blend dummy have smaller marginal effects and are only weakly significant and UNGA Voting is no longer significant. Column (6) turns to COVID lending. Regulatory Quality now enters with a highly significant and positive coefficient estimate, indicating that, in countries receiving COVID loans, better run governments receive more; Control of Corruption is no longer significant. Interestingly, we see even less evidence that COVID funding is targeted at countries that are particularly impacted. None of our COVID-related variables (\# COVID Cases, \# COVID Deaths, Growth Forecast $\Delta$ ) are statistically significant, individually or jointly. The blend dummy is no longer significant. Finally, UNGA Voting is not statistically significant, entering with a negative point estimate.

In sum, we find a link between geopolitics and which countries receive regular World Bank loans but not which countries receive COVID loans, nor how much countries receive if indeed they do receive loans. Furthermore, the link to geopolitics is not evident if we do not decompose World Bank lending by purpose in 2020 .

Table 3 focused just on the period in 2020 during which the World Bank made COVID loans. One might ask whether the selection equation findings are in some way driven by this narrow choice. Table 4 provides some evidence to address this. Columns (1) and (2) expand the sample to cover all of 2020. The results are unchanged: When including COVID lending, the link to geopolitics in World Bank lending is not apparent (Column 1) but for regular lending we still see that countries voting more in line with the U.S. are significantly more likely to receive World Bank loans, ceteris paribus (Column 2). Columns (3) and (4) demonstrate that the link between UNGA voting alignment and regular World Bank lending is not unique to 2020. Column (3) covers earlier years when the governance variables are available $(1996,1998,2000$, and 2002-2019); Column (4) drops these variables to extend the sample back to 1984 (when the U.S. State Department began identifying important votes). For both samples, geopolitical variables are statistically significant. Countries that vote in line with the U.S. on important UNGA resolutions are significantly more likely to receive regular (i.e., non-COVID) loan commitments from the World Bank; UNSC non-permanent members are also (marginally) significantly more likely to receive such commitments. ${ }^{12}$

\footnotetext{
${ }^{12}$ For the Column (4) sample, we also explore using the panel nature of the data. First, we include year dummies to allow for change over time. Second, we estimate a conditional logit with country fixed effects. The average marginal effect for UNGA voting alignment continues to be positive and statistically significant throughout. In contrast, the significance of UNSC non-permanent membership depends on the specification.
} 
Table 3 Two-part model

Selection

All

(1)

\begin{tabular}{|c|c|c|c|c|c|c|}
\hline GDP per capita (log) & $\begin{array}{l}-0.0717 \\
(-1.37)\end{array}$ & $\begin{array}{l}-0.0867 \\
(-1.43)\end{array}$ & $\begin{array}{l}-0.0246 \\
(-0.34)\end{array}$ & $\begin{array}{l}-0.0723 \\
(-0.32)\end{array}$ & $\begin{array}{l}-0.185 \\
(-1.00)\end{array}$ & $\begin{array}{l}0.181 \\
(0.75)\end{array}$ \\
\hline Population (log) & $\begin{array}{l}-0.0184 \\
(-0.69)\end{array}$ & $\begin{array}{l}0.0160 \\
(0.55)\end{array}$ & $\begin{array}{l}0.0124 \\
(0.40)\end{array}$ & $\begin{array}{l}0.582 * * * \\
(6.22)\end{array}$ & $\begin{array}{l}0.552 * * * \\
(5.55)\end{array}$ & $\begin{array}{l}0.473 * * * \\
(4.10)\end{array}$ \\
\hline Control of corruption & $\begin{array}{l}0.0715 \\
(1.15)\end{array}$ & $\begin{array}{l}0.120^{*} \\
(1.73)\end{array}$ & $\begin{array}{l}0.0220 \\
(0.27)\end{array}$ & $\begin{array}{l}0.424^{*} \\
(1.71)\end{array}$ & $\begin{array}{l}0.383^{*} \\
(1.69)\end{array}$ & $\begin{array}{l}-0.178 \\
(-0.67)\end{array}$ \\
\hline Regulatory quality & $\begin{array}{l}0.00757 \\
(0.11)\end{array}$ & $\begin{array}{l}-0.00722 \\
(-0.09)\end{array}$ & $\begin{array}{l}0.0869 \\
(1.01)\end{array}$ & $\begin{array}{l}0.362 \\
(0.91)\end{array}$ & $\begin{array}{l}0.141 \\
(0.39)\end{array}$ & $\begin{array}{l}0.940 * * * \\
(2.66)\end{array}$ \\
\hline \# COVID cases (log) & $\begin{array}{l}0.0471 * \\
(1.79)\end{array}$ & $\begin{array}{l}0.0490 * \\
(1.78)\end{array}$ & $\begin{array}{l}0.0620 * * \\
(1.98)\end{array}$ & $\begin{array}{l}0.205^{* *} \\
(2.19)\end{array}$ & $\begin{array}{l}0.153^{*} \\
(1.87)\end{array}$ & $\begin{array}{l}0.0174 \\
(0.16)\end{array}$ \\
\hline \# COVID deaths $(\log )$ & $\begin{array}{l}-0.00625 \\
(-0.24)\end{array}$ & $\begin{array}{l}-0.0135 \\
(-0.45)\end{array}$ & $\begin{array}{l}-0.0259 \\
(-0.73)\end{array}$ & $\begin{array}{l}-0.109 \\
(-0.93)\end{array}$ & $\begin{array}{l}-0.120 \\
(-1.18)\end{array}$ & $\begin{array}{l}0.0525 \\
(0.42)\end{array}$ \\
\hline Growth forecast $\Delta$ & $\begin{array}{l}0.00849 \\
(1.30)\end{array}$ & $\begin{array}{l}0.00318 \\
(0.51)\end{array}$ & $\begin{array}{l}0.00709 \\
(0.88)\end{array}$ & $\begin{array}{l}-0.00541 \\
(-0.23)\end{array}$ & $\begin{array}{l}0.00732 \\
(0.44)\end{array}$ & $\begin{array}{l}-0.0207 \\
(-0.61)\end{array}$ \\
\hline IDA & $\begin{array}{l}0.301 * * * \\
(3.54)\end{array}$ & $\begin{array}{l}0.385^{* * * *} \\
(3.58)\end{array}$ & $\begin{array}{l}0.367 * * * \\
(3.55)\end{array}$ & $\begin{array}{l}0.560 \\
(1.57)\end{array}$ & $\begin{array}{l}0.170 \\
(0.53)\end{array}$ & $\begin{array}{l}-0.253 \\
(-0.58)\end{array}$ \\
\hline blend & $\begin{array}{l}0.242 * * * \\
(5.41)\end{array}$ & $\begin{array}{l}0.373 * * * \\
(6.48)\end{array}$ & $\begin{array}{l}0.214 * * * \\
(2.63)\end{array}$ & $\begin{array}{l}0.847 * * \\
(2.48)\end{array}$ & $\begin{array}{l}0.508^{*} \\
(1.73)\end{array}$ & $\begin{array}{l}0.0176 \\
(0.04)\end{array}$ \\
\hline UNGA voting & $\begin{array}{l}0.326 \\
(1.21)\end{array}$ & $\begin{array}{l}0.860 * * * \\
(2.96)\end{array}$ & $\begin{array}{l}0.254 \\
(0.75)\end{array}$ & $\begin{array}{l}2.205^{*} \\
(1.88)\end{array}$ & $\begin{array}{l}0.510 \\
(0.46)\end{array}$ & $\begin{array}{l}-0.273 \\
(-0.25)\end{array}$ \\
\hline UNSC member & $\begin{array}{l}0.0986 \\
(0.82)\end{array}$ & $\begin{array}{l}0.0405 \\
(0.29)\end{array}$ & $\begin{array}{l}-0.0594 \\
(-0.36)\end{array}$ & $\begin{array}{l}0.193 \\
(0.74)\end{array}$ & $\begin{array}{l}0.0313 \\
(0.09)\end{array}$ & $\begin{array}{l}-0.0787 \\
(-0.17)\end{array}$ \\
\hline $\mathrm{N}$ & 141 & 141 & 141 & 108 & 87 & 93 \\
\hline
\end{tabular}

(1-3) Selection equations (probit, reporting Average Marginal Effects): All Lending; Regular Lending; COVID Lending. (4-6) Conditional Allocation (OLS): Total Loan Amount (log); Regular Loan Amount (log); COVID Loan Amount (log). z/t-statistics based on robust SEs. Unit of observation: country; sample: all countries listed as IBRD, IDA, or blend countries in World Development Indicators. Based on World Bank country-specific loans, April 2 (start of COVID lending) to December 31, 2020. For more information, see Table 1

$* \mathrm{p}<0.1 ; * * \mathrm{p}<0.05 ; * * * \mathrm{p}<0.01$

\section{Robustness checks}

In this section, we explore the robustness of our results in various dimensions. First, we provide a more complete exploration of how World Bank lending responded to differences in the impact of the pandemic across its borrowing country members. Second, we look at alternative measures of UN voting. Third, we consider issues of identification more carefully. 
Table 4 Selection with alternate samples

\begin{tabular}{|c|c|c|c|c|}
\hline & \multicolumn{2}{|c|}{2020 (full year) } & \multirow{2}{*}{$\begin{array}{l}\text { 1996-2019 } \\
\text { Regular } \\
\text { (3) }\end{array}$} & \multirow{2}{*}{$\begin{array}{l}\text { 1984-2019 } \\
\text { Regular } \\
(4)\end{array}$} \\
\hline & $\begin{array}{l}\text { All } \\
(1)\end{array}$ & $\begin{array}{l}\text { Regular } \\
\text { (2) }\end{array}$ & & \\
\hline GDP per capita (log) & $\begin{array}{l}-0.0948^{*} \\
(-1.95)\end{array}$ & $\begin{array}{l}-0.139 * * \\
(-2.47)\end{array}$ & $\begin{array}{l}-0.124 * * * \\
(-4.70)\end{array}$ & $\begin{array}{l}-0.0599 * * * \\
(-2.86)\end{array}$ \\
\hline Population (log) & $\begin{array}{l}0.0256^{*} \\
(1.91)\end{array}$ & $\begin{array}{l}0.0378^{* *} \\
(2.50)\end{array}$ & $\begin{array}{l}0.0507 * * * \\
(4.66)\end{array}$ & $\begin{array}{l}0.0763^{* * * *} \\
(9.33)\end{array}$ \\
\hline Control of corruption & $\begin{array}{l}0.0390 \\
(0.62)\end{array}$ & $\begin{array}{l}0.0500 \\
(0.80)\end{array}$ & $\begin{array}{l}-0.0853^{* *} \\
(-2.03)\end{array}$ & \\
\hline Regulatory quality & $\begin{array}{l}0.0722 \\
(1.18)\end{array}$ & $\begin{array}{l}0.0766 \\
(1.13)\end{array}$ & $\begin{array}{l}0.164 * * * \\
(3.90)\end{array}$ & \\
\hline IDA & $\begin{array}{l}0.252 * * * \\
(3.47)\end{array}$ & $\begin{array}{l}0.241^{* *} \\
(2.32)\end{array}$ & $\begin{array}{l}0.0846 \\
(1.30)\end{array}$ & $\begin{array}{l}0.0928 * \\
(1.78)\end{array}$ \\
\hline Blend & $\begin{array}{l}0.178 * * * \\
(3.09)\end{array}$ & $\begin{array}{l}0.236^{* * *} \\
(3.20)\end{array}$ & $\begin{array}{l}0.117^{*} \\
(1.87)\end{array}$ & $\begin{array}{l}0.102^{* *} \\
(2.03)\end{array}$ \\
\hline UNGA voting & $\begin{array}{l}0.264 \\
(1.05)\end{array}$ & $\begin{array}{l}0.631 * * \\
(2.34)\end{array}$ & $\begin{array}{l}0.195^{* *} \\
(2.26)\end{array}$ & $\begin{array}{l}0.331 * * * \\
(4.05)\end{array}$ \\
\hline UNSC member & $\begin{array}{l}0.0435 \\
(0.38)\end{array}$ & $\begin{array}{l}-0.0867 \\
(-0.67)\end{array}$ & $\begin{array}{l}0.0620 * \\
(1.67)\end{array}$ & $\begin{array}{l}0.0718^{* *} \\
(2.51)\end{array}$ \\
\hline $\mathrm{N}$ & 141 & 141 & 3188 & 5092 \\
\hline
\end{tabular}

(1) All Lending, full year 2020. (2) Regular Lending, full year 2020. (3) Regular Lending, 1996, 1998, 2000, 2002-2019. (4) Regular Lending, 1984-2019. z-statistics based on robust or country-clustered SEs. Unit of observation: country or country-year. Probit estimator; table reports Average Marginal Effects. Based on World Bank country-specific loans

$* \mathrm{p}<0.1 ; * \mathrm{p}<0.05 ; * * * \mathrm{p}<0.01$

\subsection{Severity of pandemic}

One notable feature of the estimation results above is the role the severity of the pandemic plays (or does not play) in lending. We might have expected the number of COVID-19 cases (or deaths) to impact whether a country received COVID loans much more than whether it received regular loans. In fact, the differential is small. Furthermore, in the conditional allocation equations, the number of COVID cases matters only if we include non-COVID lending, a rather counterintuitive result. This might be explained by the extreme circumstances of the pandemic. Governments might try to gather resources from all available sources to off-set revenue shortfalls and increased expenses (e.g., for public health or social safety net programs). And, recognizing that funding is to some extent fungible, the World Bank might increase the supply of loans even for projects not directly related to COVID response. However, this does not explain why the expected economic effect of the pandemic-which should be well measured by the change in the IMF's growth forecast-is uniformly unimportant (even if we omit \# COVID 
Cases and \# COVID Deaths). ${ }^{13}$ All this suggests taking a closer look at how we measure the impact of the pandemic.

To do this, we take several approaches. First, instead of using COVID figures up to June 30, 2020, we use figures up to December 31, 2020. Doing so does make a difference; the estimated marginal effect for \# COVID Cases is essentially unchanged for the COVID loan selection equation but becomes statistically insignificant in all other equations (including conditional allocation for COVID loans). Estimated marginal effects for other variables do not materially change. Next, we consider the health infrastructure of the country since weak health systems was a stated criterion of World Bank lending (World Bank, 2020c, p. 7). We proxy for health infrastructure quality using either Birth Attendants (the percent of births attended by skilled health staff), Health/GDP (current health expenditures as a percent of GDP), or Health/Pop (current health expenditures per capita). All these measures have the advantage of complete (or near complete) country coverage in our sample. Birth Attendents enters with an unexpected positive sign in the selection equations, statistically significant in COVID loan selection. Health/GDP is uniformly insignificant, while Health/Pop enters as negative and statistically significant, but only in regular loan selection. Finally, we look at additional measures of the pandemic's economic impact. Going beyond the change in growth forecast, we assess how dependent the economy was on international tourism (as measured by the log of international arrivals) and how much international trade dropped (as measured by the percentage change in international trade in goods from 2019 to 2020). The international arrivals variable is never significant. The change in international trade is marginally significant in COVID loan selection (with the expected negative sign) but the magnitude is trival and interpretation of results complicated by limited data availability. ${ }^{14}$ Across all these specifications, our geopolitical results remain the same.

Another approach is to question the accuracy of the reported COVID-19 data. There is substantial evidence of under-reporting (even in advanced economies) and this could vary substantially across countries. ${ }^{15}$ An alternative measure- that might be more accurate as well as capturing the broader health impact-is excess mortality. Unfortunately, few in this group of largely poor countries have reported excess morality data for 2020 (43 of the 141 countries in our sample). ${ }^{16}$ This limitation

\footnotetext{
13 In the Table 3 specifications, there is some evidence of multicollinearity between \# COVID Cases and \# COVID Deaths but nothing that materially impacts our results.

14 At this point in time, 2020 trade data in the IMF DOTS are available only for two-thirds of our sample. Results available on request.

15 For example, Tanzania's late President John Magufuli, a well-known COVID denier, suppressed reporting after April 2020. Dropping Tanzania from our sample has no impact, however.

${ }^{16}$ Excess mortality data are from https://ourworldindata.org/excess-mortality-covid, a collaboration between the Oxford Martin Programme on Global Development at the University of Oxford and the Global Change Data Lab. This is the chief source used by organizations, such as The Economist and The New York Times, for their graphics and data analysis. The WHO plans to publish data on 2020 excess mortality through its "World Health Data Hub" by the end of 2021 but notes that "[o]nly 16 of the 106 Member States in these regions [Africa, Eastern Mediterranean, South-East Asia, and Western Pacific] have sufficient data" (https://www.who.int/data/stories/the-true-death-toll-of-covid-19-estimating-globalexcess-mortality).
} 
actually underscores an important point: the appropriate variable for the COVID impact should reflect information available to the World Bank at the time. Thus, while excess mortality data (once available) might be more accurate, the real-time COVID reports are likely more appropriate for our purposes.

\subsection{UN voting}

The results reported above for UNGA voting alignment use only votes that the U.S. State Department designated as important in its annual report to Congress. US PL 101-246 mandates that the State Department report "votes on issues which directly affected important United States interests and on which the United States lobbied extensively" (U.S. State Dept. 2020, p. 10). Prior to 2019, the number of votes identified as important ranged from 7 to 19 (median 12); for 2019, the Trump administration designated 30 votes as important. This raises the possibility of an idiosyncratic definition of "important." However, the results in Table 3 (the significance of UNGA Voting only in column 2) hold if we use all UNGA votes rather than just important votes. ${ }^{17}$

Given the Trump administration's isolationist and anti-multilateral tendencies (despite having inserted a Trump loyalist as World Bank president), might other G7 members have instead exerted influence over World Bank COVID lending? Results are essentially the same using G7 UNGA voting alignment instead of U.S. UNGA voting alignment; the $\mathrm{G} 7$ point estimate in the regular loan selection equation is slightly smaller but still statistically significant. If we exclude the U.S. (G7 minus 1), the point estimate is smaller still and only marginally significant. If we include separate variables for U.S. UNGA vote alignment and G7 minus 1 UNGA vote alignment, the U.S. variable is positive and statistically significant; the G7 minus 1 variable is not. In all the permutations described above, UNGA alignment variables are not statistically significant in the other selection specifications. All this points to regular loan selection linked to U.S. voting alignment in the UNGA but COVID loan selection not linked to any of these UNGA voting patterns.

\subsection{Identification}

There are several potential challenges to identification in the above results and interpretation. First, as discussed in a prior footnote, a key identification issue is whether geopolitical variables are correlated with omitted elements of economic policy that might be the real drivers of the World Bank's supply of loans. Second, our interpretation assumes that variation in World Bank lending linked to geopolitical variables is due to variation in World Bank supply, not variation in borrower demand. We explore these issues in turn below.

\footnotetext{
17 The same holds if we instead use UNGA votes from 2020, except that UNGA voting is statistically significant in the overall conditional allocation equation. It is not statistically significant when broken out by regular or COVID though the point estimate is much smaller (and t-stat closer to zero) for COVID lending. COVID lending continues to show no link to UNGA voting.
} 
A standard critique of positive, significant findings for UNGA voting alignment with the U.S. is an omitted variable bias story: Governments that buy into radical economic policies are less likely to get World Bank funding because of these policies. However, these governments also are naturally less aligned with the U.S. on other issues and hence vote against the U.S. in the UNGA (think North Korea, Cuba, Venezuela). If we do not control appropriately for economic policies, UNGA voting alignment proxies for these policies and we get biased results, i.e., coefficient estimates that do not reflect a causal link between UNGA voting and World Bank lending.

If this is the argument, the likely direction of bias in the UNGA voting coefficient is upward. This might, therefore, explain why we get a significant positive coefficient estimate in the regular loan selection equation. The baseline specifications attempt to address this by including Control of Corruption and Regulatory Quality from the Worldwide Governance Indicators. These indicators are widely used and have the advantage of complete country coverage. However, it remains possible that the apparent significance of the geopolitical variables in the regular lending specifications was driven by omitted variable bias. As a robustness check, we explore a number of other indicators, with the caution that most do not have complete coverage. ${ }^{18}$

The additional economic policy controls we consider are the World Bank's Ease of Doing Business index $(E D B)$, inflation based on the Consumer Price Index $(C P I)$, the Current Account Balance as a percent of GDP $(B O P)$, the present value of external debt as a percent of gross national income (Debt), and the World Bank's Country Policy and Institutional Assessment (CPIA). The goal is to capture economic policy differences that the World Bank views as important and so might consider in its allocation decisions. The Ease of Doing Business index has been a centerpiece in the World Bank's public assessment of regulatory and property rights reform, sparking competition between recipient country governments to improve their ranking (Doshi et al., 2019) — and contributing to the early departure of Nobel Laureate Paul Romer from his post as World Bank Chief Economist when he questioned how scores were assigned (Zumbrun, 2018). Inflation and trade balance have long occupied an important role in World Bank assessment of a country's macroeconomic performance (Kilby, 2009). External debt is a central component of the Debt Sustainability Rating done jointly by the IMF and World Bank to assess a country's eligibility to borrow (Lang \& Presbitero, 2018). Finally, the CPIA is perhaps the ideal variable: it reflects the World Bank's own internal assessment of the country's overall economic policy quality. Its one limitation is that the World Bank makes the CPIA public only for the poorest IDA-eligible countries so that estimation samples including this variable are restricted and nonrandom.

We rerun the selection equation for Regular Lending, first adding each variable in turn to the baseline specification and then adding all at once. Summary results are reported in Table 5. Estimates for UNGA Voting are unchanged in terms of signs

\footnotetext{
18 Restricted samples could introduce sample selection issues, e.g., if results change and such changes are driven by the change in sample rather by the additional controls per se. As it turns out, the key results persist across specifications/samples.
} 
and statistical significance. Rerunning the selection equation for COVID Lending in the same fashion yields insignificant results for UNGA Voting. ${ }^{19}$ Thus, our finding of a link between geopolitics and regular lending but not between geopolitics and COVID lending is robust to including a wide range of economic policy variables that carry weight in World Bank decision-making. ${ }^{20}$

Another question that is critical for interpretation of our results is whether World Bank lending is supply- or demand-determined. Our interpretation assumes supply determines loan allocation so that the pattern we find might reflect U.S. influence over the supply of non-COVID loans but not over the supply of COVID loans. Suppose instead that supply exceeds demand (i.e., demand determines World Bank loan allocation) at least for regular loans. Further, suppose that countries not aligned with the U.S. avoid regular loans (due to conditionality, disagreement with World Bank priorities, etc.) but not COVID loans, while countries aligned with the U.S. demand both. This would generate a difference between countries for regular lending but not for COVID lending — the pattern we see-but without U.S. influence over lending decisions.

A partial response to these demand-related issues is the extensive list of country control variables (including the change in the IMF's growth forecast) that we include. Presumably these reflect demand side as well as supply side factors. This is, however, not fully satisfactory.

A further step is to look more carefully at when World Bank lending is supplydetermined versus demand-determined. It seems likely that IDA lend is supplyconstrained (given very favorable terms for borrowers and limited finances available for IDA) while IBRD lending could well be determined by demand. Thus, if the effect we estimate were in fact demand-driven, the pattern (significant UNGA Voting marginal effect for regular loan selection; insignificant for COVID loan selection) should not hold for the IDA sub-sample.

Taking advantage of this, Table 6 repeats Table 3 but just using lending to IDAonly countries (i.e., countries that are only eligible to borrower from the IDA). The results closely mirror those in Table 3 and support the supply-side view: UNGA voting remains positive and significant for regular loan eligibility and insignificant (with a much smaller average marginal effect) for COVID loan eligibility. ${ }^{21}$ Thus, if we believe that countries want as much highly concessional IDA funding as they can get, the results are consistent with interpreting the findings as evidence of the U.S. exercising influence over regular lending but not over COVID lending.

\footnotetext{
19 Results available from authors. We omit them here because the omitted variable bias story outlined above is not likely to explain the (generally) insignificant results in COVID loan selection equation (or in the conditional allocation equations, for that matter).

${ }^{20}$ In Table 5 UNSC Member is never significant. Also, following Bechtel and Ziegler (2019) we explore a quadratic specification for UNGA Voting. Neither the linear nor the quadratic term is individually significant and the implied peak is at the $98^{\text {th }}$ percentile, i.e., there is little evidence of an inverted-U.

21 With this substantially smaller sample, we have to drop the UNSC Member dummy as its marginal effect is not identified in the probit equation. The sample restriction also requires us to drop the $I D A$ and blend dummies as they are perfectly collinear with the constant term.
} 


\section{Conclusion}

Despite a history of politicized World Bank lending, we find no evidence that countries favored by the U.S.- the dominant shareholder-received special treatment in the World Bank's response to the COVID-19 pandemic in 2020. This is in contrast to regular lending (in 2020 and earlier), where we find that countries voting in line with the U.S. in the UNGA were significantly more likely to receive loans, ceteris paribus. We argue that this pattern reflects the U.S. exercising influence over regular World Bank lending but not over COVID lending because the pattern persists with extensive policy controls and when we examine only supplyconstrained IDA lending.

An interesting and important question is why pandemic lending is not subject to the same power-based geopolitical influence evident in regular loans. Did the U.S. pressure World Bank management with regard to regular lending but fail to do so for the COVID-19 fast track facility? Or did World Bank management resist pressure in the case of COVID loans? Clark and Dolan (2021) examine conditionality in World Bank development policy lending and argue that U.S. preferences shape World Bank policy indirectly, with staff consciously or unconsciously designing and implementing programs consistent with U.S. interests. If so, the evidence from this paper suggests that a different mechanism may be at play in the case of pandemic response. Kreuder-Sonnen (2019) explores cases of "authority leaps" as international organizations respond to crises via "assertive governance" that expands their scope of operations, justifying their actions as political necessity. The case of World Bank COVID lending provides an interesting twist as the institution appears to hew more closely to its charter mandate in its crisis response than in its ordinary business.

Tempering this finding, we also uncover scant evidence that the World Bank targets its COVID lending based on the measurable impact of the pandemic. The estimated effects of variables that directly capture the health/economic impact of the pandemic or that reflect the risk of such impacts (other than the pre-pandemic income level) are either statistically insignificant or economically insignificant in our COVID lending models. For example, one percent more reported COVID cases is associated with only a 0.06 percentage point increase in the probability of receiving a COVID loan, on average and ceteris paribus. None of the other factors we consider that reflect the severity of the pandemic in the recipient country or the country's vulnerability to economic loss are significant in determining either eligibility for loans or the volume of lending.

The World Bank is not the only IFI or donor to respond to pandemic-related financial distress. The IMF has provided debt service relief to 29 countries through its Catastrophe Containment and Relief Trust (CCRT) for debts due between April 2020 and October 2021; this window may be extended to April 2022. The CCRT provides grant-based relief and was originally set up in 2015 for countries impacted by Ebola. The IMF also reports a substantial increase in new lending to low-income countries since the start of the pandemic. An increased 
Table 5 Selection with additional policy controls

Selection

Regular Regular Regular Regular Regular Regular

(1)

(2)

(3)

(4)

(5)

(6)

\begin{tabular}{|c|c|c|c|c|c|c|}
\hline UNGA voting & $\begin{array}{l}0.902 * * * \\
(3.11)\end{array}$ & $\begin{array}{l}0.903 * * * \\
(2.91)\end{array}$ & $\begin{array}{l}0.878^{* * * *} \\
(2.95)\end{array}$ & $\begin{array}{l}0.824 * * \\
(2.20)\end{array}$ & $\begin{array}{l}1.262^{* * * *} \\
(3.34)\end{array}$ & $\begin{array}{l}1.291 * * * \\
(3.19)\end{array}$ \\
\hline EDB & $\begin{array}{l}0.00702 \\
(1.44)\end{array}$ & & & & & $\begin{array}{l}-0.00771 \\
(-1.55)\end{array}$ \\
\hline CPI & & $\begin{array}{l}-0.000256 \\
(-0.25)\end{array}$ & & & & $\begin{array}{l}0.00725 \\
(1.16)\end{array}$ \\
\hline BOP & & & $\begin{array}{l}0.00105 \\
(0.72)\end{array}$ & & & $\begin{array}{l}-0.00726^{*} \\
(-1.87)\end{array}$ \\
\hline Debt & & & & $\begin{array}{l}0.00137 \\
(0.85)\end{array}$ & & $\begin{array}{l}0.000907 \\
(0.94)\end{array}$ \\
\hline CPIA & & & & & $\begin{array}{l}-0.149 * \\
(-1.96)\end{array}$ & $\begin{array}{l}-0.0654 \\
(-0.71)\end{array}$ \\
\hline $\mathrm{N}$ & 138 & 132 & 139 & 117 & 84 & 75 \\
\hline
\end{tabular}

Dependent variable: Regular Lending. Probit estimator; table reports Average Marginal Effects. Z-statistics based on robust SEs. Unit of observation: country. Based on World Bank country-specific loans. All specifications include GDP per Capita (log), Population (log), Control of Corruption, Regulatory Quality, \# COVID Cases (log), and \# COVID Deaths (log). (1-4) include UNSC Member; samples for (5) \& (6) do not include any non-permanent UNSC members

$* \mathrm{p}<0.1 ; * * \mathrm{p}<0.05 ; * * * \mathrm{p}<0.01$

allocation of $\$ 650$ billion in IMF special drawing rights (SDRs) appears likely and may provide additional resources to hard-hit countries (IMF, 2021a). Together, the World Bank and the IMF called on official bilateral creditors to provide debt relief as part of the Debt Service Suspension Initiative (DSSI). Since taking effect in May 2020, the DSSI has provided over \$5 billion in "relief" (i.e., temporary suspension of debt service payments to official creditors) to 43 countries (out of 73 deemed eligible) (World Bank, 2021a). Countries are to make good on their suspended payments over the next three to five years, after an initial one year grace period. The G20 agreed on a Common Framework for Debt Treatments, a particularly important step since this group includes non-Paris Club countries, most notably China. This seeks to provide a more long-term approach to mounting low-income country debt than does the DSSI and requires that countries seeking official debt relief also approach their private creditors (IMF,2021b). Thus, an open question is the degree to which geopolitics shape these other initiatives since a distorted allocation would reduce their effectiveness in addressing the impact of the novel coronavirus. 
Table 6 IDA subsample

Selection

All

(1)

\begin{tabular}{lllllll}
\hline GDP per capita $(\log )$ & -0.0205 & 0.0395 & -0.0215 & 0.112 & -0.162 & 0.372 \\
& $(-0.82)$ & $(0.57)$ & $(-0.49)$ & $(0.41)$ & $(-0.90)$ & $(1.30)$ \\
Population $(\log )$ & -0.0487 & -0.0278 & -0.0146 & $0.593 * * *$ & $0.639 * * *$ & $0.407 * *$ \\
& $(-1.42)$ & $(-0.74)$ & $(-0.41)$ & $(4.40)$ & $(4.73)$ & $(2.45)$ \\
Control of corruption & -0.0250 & 0.105 & -0.0502 & 0.352 & 0.338 & -0.432 \\
& $(-0.54)$ & $(1.06)$ & $(-0.66)$ & $(1.11)$ & $(1.59)$ & $(-1.06)$ \\
Regulatory quality & $0.120 *$ & -0.0366 & $0.391 * * *$ & 0.275 & 0.294 & 0.391 \\
& $(1.95)$ & $(-0.32)$ & $(6.04)$ & $(0.59)$ & $(0.86)$ & $(0.55)$ \\
\# COVID cases $(\log )$ & 0.0427 & $0.105 * * *$ & $0.0785 * * *$ & 0.156 & 0.0494 & 0.0427 \\
& $(1.36)$ & $(2.71)$ & $(2.65)$ & $(1.49)$ & $(0.62)$ & $(0.31)$ \\
\# COVID deaths $(\log )$ & -0.00104 & -0.0530 & $-0.0589 * *$ & -0.0306 & -0.0290 & 0.00673 \\
& $(-0.06)$ & $(-1.28)$ & $(-1.97)$ & $(-0.18)$ & $(-0.27)$ & $(0.03)$ \\
Growth forecast $\Delta$ & -0.00191 & -0.0423 & -0.00158 & 0.00818 & 0.0114 & 0.0190 \\
& $(-0.15)$ & $(-1.51)$ & $(-0.29)$ & $(0.37)$ & $(0.82)$ & $(0.91)$ \\
UNGA voting & 0.130 & $1.494 * * *$ & 0.391 & 1.856 & 0.142 & -0.359 \\
N & $(0.76)$ & $(3.14)$ & $(1.29)$ & $(1.10)$ & $(0.09)$ & $(-0.23)$ \\
\hline
\end{tabular}

(1-3) Selection equations (probit): All Lending; Regular Lending; COVID Lending. (4-6) Conditional Allocation (OLS): Total Loan Amount (log); Regular Loan Amount (log); COVID Loan Amount (log). z/t-statistics based on robust SEs. Unit of observation: country; sample: only countries listed as IDA countries in World Development Indicators. Based on World Bank country-specific loans, April 2 (start of COVID lending) to December 31, 2020. For more information, see Table 1

$* \mathrm{p}<0.1 ; * * \mathrm{p}<0.05 ; * * * \mathrm{p}<0.01$

One important reason why COVID lending is unique is because it funds an international public good with a high level of urgency and salience for all major IFI shareholders. The same cannot be said of other international public goods. ${ }^{22}$ For example, funding for climate change mitigation aims to battle a problem that is far

\footnotetext{
22 The classic enlightened self-interest argument for aid holds that economic development itself is an international public good. This follows if richer countries are better trading partners, have lower rates of population growth, contribute less to climate change, are less prone to conflicts and violence that spill outside their borders, or are less likely to be the source of emerging infectious diseases. As Kanbur (2002) points out, this hinges on the assumption that aid —in this case, World Bank lending-promotes economic develop, a point still debated in the theoretical (Brecher \& Bhagwati, 1982) and empirical literatures (Doucouliagos \& Paldam, 2008). The causal role of economic growth in demographic transitions is still the subject of some debate (e.g., Dyson, 2010), even more so the existence of an environmental Kuznets curve (Stern, 2004). Links between income and conflict are complex at best, e.g., with some finding a positive link between income and terrorism (Blomberg et al., 2004) and others finding a negative link between income shocks and civil conflict (Miguel et al., 2004). In short, the link between regular World Bank lending and international public goods is much more indirect and tenuous than the link between COVID World Bank lending and international public goods.
} 
enough in the future as to render it an abstraction that relies on considerable faith in the scientific community to acknowledge. Doing so also risks reciprocal obligations on countries, not just as donors but also for their domestic policies, and so raises the political and economic stakes to the point that some prefer procrastination and denial to active engagement. While COVID-19 has been equally contentious in domestic politics, either because of electoral considerations or because of a tension between individual liberty and collective welfare mediated by the uncertainties of an infectious disease with a variable prognosis, the international dimension (before wide-spread vaccination) is in some ways more straightforward. The health and economic impacts of the virus are clear. Since the pandemic was created by cross-border infection, the benefits of reducing the infection rate in distant countries are tangible. International supply chain issues and concerns over falling export demand underscore the economic advantages of physically healthy trading partners. The sums involved to fund World Bank lending and other international programs are dwarfed both by the pandemic's impact and by domestic stimulus packages in rich countries. Finally, excepting vaccine provision, few reciprocal obligations are created for donor countries. The combination of these factors may have tilted the U.S. cost-benefit analysis in favor of the international public goods benefits from providing COVID loans irrespective of geopolitics, in line with Bermeo's (2018) notion of targeted development.

Looking beyond loans, the G7 countries have pledged to donate over a billion vaccine doses to poor countries (WHO, 2021), an important start to addressing the problem but far, far short of the 13 billion needed. As a result, COVAX - the attempt at international coordination of vaccine supply — has failed to deliver anything close the promised number of vaccines to poor countries (Anna, 2021). Setting aside vaccine availability, vaccination campaigns historically have been difficult because of a lack of infrastructure and local apprehensions and politics. Given the nature of the pandemic and of the vaccines themselves, the challenges are likely to be still greater for COVID-19. Already some countries (e.g., the Democratic Republic of the Congo, Malawi, Nigeria and South Sudan) report problems administering what supplies they did receive (Mwai, 2021). Overcoming these major challenges-while clearly difficult-is more likely if the U.S. and other donor countries continue to see the fight against the virus as a priority IPG issue.

However, as Bollyky and Bown (2020) point out, the situation may change dramatically as COVID-19 vaccination rates continue to rise in rich countries-and not only for the better. So long as rich countries have not reached herd immunity and the potential for variants to spread from poor to rich countries persists, support for international efforts focused on disease containment and vaccination will likely continue, despite the challenges. That is, the international public goods benefit is large. But regardless of their superior efficacy, support for internationally funded inoculation programs may well revert to politics as usual over time. The more effective the vaccine is in rich countries - including against emerging variants-and thus the more that the health of vaccinated populations is independent of the health of other populations, the less likely global public health concerns will continue to dominate decision-making. In a perhaps ironic twist looking at the U.S., those without a college degree are the most hesitant to get the COVID-19 vaccine (Thomas et al., 2021) 
and thus would receive the largest benefit from fighting the virus abroad. Yet the same demographic historically has been the least supportive of the foreign aid that might accomplish this (Milner \& Tingley, 2013), hardly the recipe for success.

\section{Appendix}

See Table 7.

Table 7 Regular Lending and COVID Lending dummies

\begin{tabular}{|c|c|c|}
\hline \multirow[t]{2}{*}{ Country } & \multicolumn{2}{|l|}{ Loans } \\
\hline & Regular & COVID \\
\hline Afghanistan & 1 & 1 \\
\hline Albania & 1 & 1 \\
\hline Algeria & 0 & 0 \\
\hline Angola & 0 & 0 \\
\hline Antigua and Barbuda & 0 & 0 \\
\hline Argentina & 0 & 1 \\
\hline Armenia & 0 & 0 \\
\hline Azerbaijan & 0 & 0 \\
\hline Bangladesh & 1 & 1 \\
\hline Belarus & 1 & 1 \\
\hline Belize & 0 & 0 \\
\hline Benin & 1 & 1 \\
\hline Bhutan & 1 & 1 \\
\hline Bolivia & 0 & 1 \\
\hline Bosnia and Herzegovina & 0 & 1 \\
\hline Botswana & 0 & 0 \\
\hline Brazil & 1 & 1 \\
\hline Bulgaria & 0 & 0 \\
\hline Burkina Faso & 1 & 1 \\
\hline Burundi & 0 & 1 \\
\hline Cabo Verde & 1 & 1 \\
\hline Cambodia & 1 & 1 \\
\hline Cameroon & 1 & 1 \\
\hline Central African Republic & 1 & 1 \\
\hline Chad & 1 & 1 \\
\hline Chile & 0 & 0 \\
\hline China & 1 & 1 \\
\hline Colombia & 1 & 1 \\
\hline Comoros & 1 & 1 \\
\hline Congo, Dem Rep & 1 & 1 \\
\hline Congo, Rep & 1 & 1 \\
\hline Costa Rica & 1 & 0 \\
\hline Cote d'Ivoire & 1 & 1 \\
\hline
\end{tabular}


Table 7 (continued)

\begin{tabular}{|c|c|c|}
\hline \multirow[t]{2}{*}{ Country } & \multicolumn{2}{|l|}{ Loans } \\
\hline & Regular & COVID \\
\hline Croatia & 1 & 1 \\
\hline Djibouti & 1 & 1 \\
\hline Dominica & 1 & 0 \\
\hline Dominican Republic & 0 & 1 \\
\hline Ecuador & 1 & 1 \\
\hline Egypt, Arab Rep & 1 & 1 \\
\hline El Salvador & 0 & 1 \\
\hline Equatorial Guinea & 0 & 0 \\
\hline Eritrea & 0 & 0 \\
\hline Eswatini & 1 & 1 \\
\hline Ethiopia & 1 & 1 \\
\hline Fiji & 0 & 1 \\
\hline Gabon & 0 & 1 \\
\hline Gambia, The & 1 & 1 \\
\hline Georgia & 1 & 1 \\
\hline Ghana & 1 & 1 \\
\hline Grenada & 1 & 1 \\
\hline Guatemala & 1 & 1 \\
\hline Guinea & 1 & 1 \\
\hline Guinea-Bissau & 1 & 0 \\
\hline Guyana & 1 & 1 \\
\hline Haiti & 1 & 1 \\
\hline Honduras & 1 & 1 \\
\hline India & 1 & 1 \\
\hline Indonesia & 1 & 1 \\
\hline Iran, Islamic Rep & 0 & 1 \\
\hline Iraq & 0 & 0 \\
\hline Jamaica & 0 & 0 \\
\hline Jordan & 1 & 1 \\
\hline Kazakhstan & 1 & 0 \\
\hline Kenya & 1 & 1 \\
\hline Kiribati & 1 & 1 \\
\hline Kyrgyz Republic & 1 & 1 \\
\hline Lao PDR & 0 & 1 \\
\hline Lebanon & 0 & 0 \\
\hline Lesotho & 0 & 1 \\
\hline Liberia & 1 & 1 \\
\hline Libya & 0 & 0 \\
\hline Madagascar & 1 & 1 \\
\hline Malawi & 1 & 1 \\
\hline Malaysia & 0 & 0 \\
\hline Maldives & 1 & 1 \\
\hline
\end{tabular}


Table 7 (continued)

\begin{tabular}{|c|c|c|}
\hline \multirow[t]{2}{*}{ Country } & \multicolumn{2}{|l|}{ Loans } \\
\hline & Regular & $\overline{\text { COVID }}$ \\
\hline Mali & 0 & 1 \\
\hline Marshall Islands & 1 & 1 \\
\hline Mauritania & 1 & 1 \\
\hline Mauritius & 0 & 0 \\
\hline Mexico & 1 & 1 \\
\hline Micronesia, Fed Sts & 1 & 0 \\
\hline Moldova & 1 & 1 \\
\hline Mongolia & 1 & 1 \\
\hline Montenegro & 0 & 0 \\
\hline Morocco & 1 & 1 \\
\hline Mozambique & 1 & 1 \\
\hline Myanmar & 1 & 1 \\
\hline Namibia & 0 & 0 \\
\hline Nauru & 0 & 0 \\
\hline Nepal & 1 & 1 \\
\hline Nicaragua & 0 & 1 \\
\hline Niger & 1 & 1 \\
\hline Nigeria & 1 & 1 \\
\hline North Macedonia & 1 & 1 \\
\hline Pakistan & 1 & 1 \\
\hline Palau & 0 & 0 \\
\hline Panama & 0 & 1 \\
\hline Papua New Guinea & 1 & 1 \\
\hline Paraguay & 0 & 1 \\
\hline Peru & 1 & 0 \\
\hline Philippines & 1 & 1 \\
\hline Poland & 0 & 0 \\
\hline Romania & 0 & 0 \\
\hline Russian Federation & 0 & 0 \\
\hline Rwanda & 1 & 1 \\
\hline Samoa & 1 & 1 \\
\hline Sao Tome and Principe & 1 & 1 \\
\hline Senegal & 1 & 1 \\
\hline Serbia & 0 & 1 \\
\hline Seychelles & 0 & 1 \\
\hline Sierra Leone & 1 & 1 \\
\hline Solomon Islands & 1 & 0 \\
\hline Somalia & 1 & 0 \\
\hline South Africa & 0 & 0 \\
\hline South Sudan & 1 & 0 \\
\hline Sri Lanka & 1 & 1 \\
\hline St Kitts and Nevis & 0 & 0 \\
\hline
\end{tabular}


Table 7 (continued)

\begin{tabular}{lll}
\hline Country & Loans & \\
\cline { 2 - 3 } & Regular & COVID \\
\hline St Lucia & 1 & 0 \\
St Vincent and the Grenadines & 1 & 0 \\
Sudan & 1 & 0 \\
Suriname & 0 & 0 \\
Tajikistan & 1 & 1 \\
Tanzania & 0 & 0 \\
Thailand & 0 & 0 \\
Timor-Leste & 1 & 0 \\
Togo & 0 & 1 \\
Tonga & 1 & 1 \\
Trinidad and Tobago & 0 & 1 \\
Tunisia & 0 & 1 \\
Turkey & 1 & 1 \\
Turkmenistan & 0 & 0 \\
Tuvalu & 1 & 0 \\
Uganda & 1 & 1 \\
Ukraine & 1 & 1 \\
Uruguay & 0 & 1 \\
Uzbekistan & 1 & 1 \\
Vanuatu & 0 & 0 \\
Venezuela, RB & 0 & 0 \\
Vietnam & 1 & 0 \\
Zambia & 0 & \\
Zimbabwe & 1 & \\
\hline & 0 & 0 \\
\hline
\end{tabular}

Author contributions Author contributions to research design and conceptualization: CK (90\%), CM (10\%); statistical analysis: CK (100\%), CM (0\%); writing: CK (75\%), CM (25\%); data collection \& literature review: CK (75\%), CM (25\%).

\section{References}

Alesina, A., \& Dollar, D. (2000). Who gives aid to whom and why? Journal of Economic Growth, 5(1), 33-63.

Anna, C. (2021). Africa's COVID-19 envoy blasts EU, COVAX over vaccine crisis. Washington Post. July 1. https://www.washingtonpost.com/politics/africas-covid-19-envoy-blasts-eu-covax-over-vacci ne-crisis/2021/07/01/82ca7054-da58-11eb-8c87-ad6f27918c78_story.html

Annen, K., \& Strickland, S. (2017). Global Samaritans? Donor election cycles and the allocation of humanitarian aid. European Economic Review, 96, 38-47.

Bechtel, M. M., \& Ziegler, J. (2019). Foreign policy interests and international disaster assistance. SSRN Working Paper \#3472528.

Bermeo, S. B. (2018). Targeted development: Industrialized country strategy in a globalizing world. Oxford University Press. 
Blomberg, S. B., Hess, G. D., \& Weerapana, A. (2004). Economic conditions and terrorism. European Journal of Political Economy, 20(2), 463-478.

Bollyky, T. J., \& Bown, C. P. (2020). The tragedy of vaccine nationalism: Global cooperation on vaccine allocation would be the most efficient way to disrupt the spread of the virus. Foreign Affairs July 27 , 2020. https://www.foreignaffairs.com/articles/united-states/2020-07-27/vaccine-nationalism-pande mic

Brecher, R. A., \& Bhagwati, J. N. (1982). Immiserizing transfers from abroad. Journal of International Economics, 13(3-4), 353-364.

Bretton Woods Project. (2020). The IMF and World Bank-led Covid-19 recovery: 'Building back better' or locking in broken policies? Bretton Woods Observer, Summer 2020, 1-2.

Cameron, A. C., \& Trivedi, P. K. (2005). Microeconometrics: Methods and applications. Cambridge University Press.

Clark, R., \& Dolan, L. (2021). Pleasing the principal: U.S. influence in World Bank policymaking. American Journal of Political Science, 65(1), 36-51.

Collier, P., \& Dollar, D. (2002). Aid allocation and poverty reduction. European Economic Review, 46(8), $1475-1500$.

Deaton, A. (2010). Instruments, randomization, and learning about development. Journal of Economic Literature, 48(2), 424-455.

Dimakou, O., Romero, M. J., \& Van Waeyenberge, E. (2021). Never let a pandemic go to waste: Turbocharging the private sector for development at the World Bank. Canadian Journal of Development Studies, 42(1-2), 221-237.

Dong, E., Du, H., \& Gardner, L. (2020). An interactive web-based dashboard to track COVID-19 in real time. Lancet Infectious Disease, 20(5), 533-534. https:/github.com/CSSEGISandData/COVID-19/ tree/master/csse_covid_19_data/csse_covid_19_daily_reports

Doshi, R., Kelley, J., \& Simmons, B. (2019). The power of ranking: The Ease of Doing Business indicator and global regulatory behavior. International Organization, 73(3), 611-643.

Doucouliagos, H., \& Paldam, M. (2008). Aid effectiveness on growth: A meta study. European Journal of Political Economy, 24(1), 1-24.

Dreher, A., Klasen, S., Vreeland, J. R., \& Werker, E. (2013). The costs of favoritism: Is politically driven aid less effective? Economic Development and Cultural Change, 62(1), 157-191.

Dreher, A., Lang, V., Rosendorff, B. P., \& Vreeland, J. R. (2018). Buying votes and international organizations: The dirty work-hypothesis. CEPR Discussion Paper No. 13290.

Dreher, A., Sturm, J.-E., \& Vreeland, J. R. (2009). Development aid and international politics: Does membership on the UN Security Council influence World Bank decisions? Journal of Development Economics, 88(1), 1-18.

Drury, A. C., Olson, R. S., \& Van Belle, D. A. (2005). The politics of humanitarian aid: US foreign disaster assistance, 1964-1995. The Journal of Politics, 67(2), 454-473.

Duggan, J., Morris, S., Sandefur, J., \& Yang, G. (2020). Is the World Bank's COVID-19 crisis lending big enough, fast enough? New evidence on loan disbursements. CGD Working Paper 554. Washington, DC: Center for Global Development. https:/www.cgdev.org/publication/world-banks-covidcrisis-lending-bigenough-fast-enough-new-evidence-loan-disbursements

Dyson, T. (2010). Population and development: The demographic transition. Zed Books.

EM-DAT. 2020. The Emergency Events Database-Université Catholique de Louvain (UCL) —CRED, D. Guha-Sapir-www.emdat.be, Brussels, Belgium.

Gibson, J. (2019). Are you estimating the right thing? An editor reflects. Applied Economic Perspectives and Policy, 41(3), 329-350.

International Monetary Fund (IMF) (2020). World Economic Outlook Database. Retrieved June 14, 2021, from https://www.imf.org/en/Publications/WEO/weo-database/2021/April/download-entiredatabase

International Monetary Fund (IMF) (2021a). Questions and answers: The IMF's response to COVID-19. Retrieved April 8, 2021, from https://www.imf.org/en/About/FAQ/imf-response-to-covid-19

International Monetary Fund (IMF) (2021b). Questions and answers on sovereign debt issues. Retrieved April 8, 2021, from https://www.imf.org/en/About/FAQ/sovereign-debt\#s2q1

Kanbur, S. M. R. (2002). International financial institutions and international public goods: Operational implications for the World Bank. G-24 Discussion Paper \# 19.

Kaya, A. (2015). Power and global economic institutions. Cambridge University Press.

Kersting, E., \& Kilby, C. (2016). With a little help from my friends: Global electioneering and World Bank lending. Journal of Development Economics, 121, 153-165. 
Kersting, E., \& Kilby, C. (2019). The rise of supplemental lending at the World Bank. Canadian Journal of Economics, 52(4), 1655-1698.

Kersting, E., \& Kilby, C. (2021). Do domestic politics shape U.S. influence in the World Bank? Review of International Organizations, 16(1), 29-58. https://doi.org/10.1007/s11558-018-9321-8

Kevlihan, R., DeRouen, K., Jr., \& Biglaiser, G. (2014). Is US humanitarian aid based primarily on need or self-interest? International Studies Quarterly, 58(4), 839-854.

Kilby, C. (2009). The political economy of conditionality: An empirical analysis of World Bank loan disbursements. Journal of Development Economics, 89(1), 51-61.

Kilby, C. (2013a). An empirical assessment of informal influence in the World Bank. Economic Development and Cultural Change, 61(2), 431-464.

Kilby, C. (2013b). The political economy of project preparation: An empirical analysis of World Bank projects. Journal of Development Economics, 105, 211-225.

Kilby, C. (2015). Assessing the impact of World Bank preparation on project outcomes. Journal of Development Economics, 115, 111-123.

Kilby, C., \& Dreher, A. (2010). The impact of aid on growth revisited: Do donor motives matter? Economics Letters, 107(3), 338-340.

Kilby, C., \& Michaelowa, K. (2019). What influences World Bank project evaluations? In N. Dutta, \& C. Williamson (Eds.), Lessons on foreign aid and economic development: Micro and macro perspectives (pp. 105-150). Palgrave/McMillan.

Kreuder-Sonnen, C. (2019). International authority and the emergency problematique: IO empowerment through crises. International Theory, 11(2), 182-210.

Lang, V. F., \& Presbitero, A. F. (2018). Room for discretion? Biased decision-making in international financial institutions. Journal of Development Economics, 130, 1-16.

Miguel, E., Satyanath, S., \& Sergenti, E. (2004). Economic shocks and civil conflict: An instrumental variables approach. Journal of Political Economy, 112(4), 725-753.

Milner, H. V., \& Tingley, D. (2013). Public opinion and foreign aid: A review essay. International Interactions, 39(3), 389-401.

Morgenthau, H. (1962). A political theory of foreign aid. American Political Science Review, 56(2), 301-309.

Morris, S., Sandefur, J., \& Yang, G. (2021). Tracking the scale and speed of the World Bank's COVID response: April 2021 update. CGD Notes. April 5, 2021. https://www.cgdev.org/publication/track ing-scale-and-speed-world-banks-covid-response-april-2021-update

Mwai, P. (2021). Covid-19 vaccines: Why some African states can't use their vaccines. BBC News. Retrieved June 8, 2021, from https://www.bbc.com/news/56940657

Ruttan, V. W. (1996). United States development assistance policy: The domestic politics of foreign economic aid. Johns Hopkins University Press.

Stern, D. I. (2004). The rise and fall of the environmental Kuznets curve. World Development, 32(8), 1419-1439.

Thomas, K., Darling, J., \& Cassil, A. (2021). COVID-19 vaccine hesitancy: Education divide widens. USC Dornsife Center for Economic and Social Research Data Brief No. 2, February 2021. https:// uasdata.usc.edu/index.php?r=eNpLtDKyqi62MrFSKkhMT1WyLrYyNAeyS5NyMpP1UhJLE vUSU1Ly80ASQDWJKZkpIKax1ZK5mYWSdS1cMG04Euo

United Nations (UN). (2020a). United Nations Digital Library_Voting Data. https://digitallibrary.un.org/ search? $1 n=$ en $\& c c=$ Voting + Data

United Nations (UN). (2020b). United Nations Security Council-Current Members. https://www.un.org/ securitycouncil/content/current-members

United States Department of State (U.S. State Dept.). (2020). Voting practices in the United Nations for 2019.

Vreeland, J. R., \& Dreher, A. (2014). The political economy of the United Nations Security Council: Money and influence. Cambridge University Press.

Wang, T. Y. (1999). US foreign aid and UN voting: An analysis of important issues. International Studies Quarterly, 43(1), 199-210.

World Bank (2020a). Amid multiple crises, World Bank Group refocuses programs and increases financing to $\$ 74$ billion in fiscal year 2020. July 10, 2020. https://www.worldbank.org/en/news/press-relea se/2020/07/10/amid-multiple-crises-world-bank-group-refocuses-programs-and-increases-finan cing-to-74-billion-in-fiscal-year-2020

World Bank. (2020b). Project appraisal document on a COVID-19 Strategic Preparedness and Response Program and proposed 25 projects under Phase 1 using the Mulitphase Programmatic Approach. 
Report No: PCBASIC0219761. (April 2, 2020) https://documents1.worldbank.org/curated/en/99337 1585947965984/pdf/World-COVID-19-Strategic-Preparedness-and-Response-Project.pdf

World Bank. (2020c). Saving lives, scaling-up impact and getting back on track: World Bank Group COVID-19 crisis response approach paper. June 2020.

World Bank. (2020e). World Bank COVID-19 Response. October 14, 2020. https://www.worldbank.org/ en/news/factsheet/2020/10/14/world-bank-covid-19-response

World Bank. (2021a). Brief: COVID-19: Debt Service Suspension Initiative. Retrieved June 18, 2021, from https://www.worldbank.org/en/topic/debt/brief/covid-19-debt-service-suspension-initiative

World Bank. (2021b). World Bank projects database. https://projects.worldbank.org/en/projects-opera tions/project-search?lang=en

World Bank. (WDI). (2020). World development indicators. https://databank.worldbank.org/reports.aspx? source $=$ world-development-indicators

World Bank (WGI). (2020). Worldwide governance indicators. https://databank.worldbank.org/source/ worldwide-governance-indicators

World Health Organizations (WHO). (2021). G7 announces pledges of 870 million COVID-19 vaccine doses, of which at least half to be delivered by the end of 2021. Retrieved June 13, 2021, from https://www.who.int/news/item/13-06-2021-g7-announces-pledges-of-870-million-covid-19-vacci ne-doses-of-which-at-least-half-to-be-delivered-by-the-end-of-2021

Zimmerman, R. F. (1993). Dollars, diplomacy, \& development. Boulder: Lynne Rienner.

Zumbrun, J. (2018). Chief Economist at World Bank quits. The Wall Street Journal 01/25/2018. https:// www.wsj.com/articles/world-bank-chief-economist-paul-romer-resigns- 1516823370

\section{Further Reading}

World Bank. (2020d). World Bank Group's operational response to COVID-19 (coronavirus)—Projects list. July 17, 2020. https://www.worldbank.org/en/about/what-we-do/brief/world-bank-group-opera tional-response-covid-19-coronavirus-projects-list

Publisher's note Springer Nature remains neutral with regard to jurisdictional claims in published maps and institutional affiliations. 